\title{
Influence of monsoon-driven hydrographic features on thaliacean distribution in waters around Taiwan, western North Pacific Ocean
}

\author{
Zhen-Heng Liao ${ }^{1}$, Hung-Yen Hsieh ${ }^{2,3}$ and Wen-Tseng Lo ${ }^{1 *}$
}

\begin{abstract}
Background: The mesoscale distribution of thaliaceans associated with hydrographic conditions in the waters around Taiwan was investigated during two different monsoon seasons in 2004 in order to elucidate possible influences of hydrological conditions driven by seasonal monsoons on distributional patterns of thaliaceans.

Results: In total, 18 thaliacean species, belonging to 12 genera and 3 families, were identified in our samples. Thalia rhomboides, Doliolum denticulatum, Doliolum nationalis, Thalia orientalis, Pyrosoma verticillatum, and Thalia democratica were the six predominant species and contributed $93 \%$ to the total thaliacean collection by number. Thaliacean assemblages were similar in composition between seasons, but abundances and species numbers were higher in summer than in winter. Spatial distribution patterns of doliolids and salps clearly differed and were closely associated with hydrographic characteristics. Doliolids were mainly found in lower-salinity and nutrient-rich shelf and neritic waters; among them, D. denticulatum could be used as an indicator species of the China Coastal Current. Most salp species showed higher abundances in warm oceanic waters, such as the Kuroshio Current, Kuroshio Branch Current, and South China Sea Surface Current.
\end{abstract}

Conclusions: This study showed that the succession of water masses driven by monsoons affects seasonal and particularly spatial distributions of abundances of the thaliacean assemblage in the area studied.

Keywords: Monsoon; Water mass; Taiwan; Thaliacean; Distribution

\section{Background}

Oceanic waters surrounding Taiwan are dominated by several water masses (Figure 1) that are affected by seasonal monsoons (Jan et al. 2002, 2006). There are three main oceanic currents in the Taiwan Strait (TS): the China Coastal Current (CCC), South China Sea Surface Current (SCSSC), and Kuroshio Branch Current (KBC). These currents are strongly influenced by monsoons and seasonally change their direction and succession. Each of these currents plays a significant role in shaping hydrographic conditions in the TS (Jan et al. 2002). On the other hand, the warm and highly saline Kuroshio Current (KC) (Yang et al. 1999), which originates in the northern tropical Pacific east of the Philippines, flows northward along waters east of Taiwan year-round.

\footnotetext{
* Correspondence: lowen@faculty.nsysu.edu.tw

1 Institute of Marine Biotechnology and Resources, National Sun Yat-sen

University, Kaohsiung 80424, Taiwan

Full list of author information is available at the end of the article
}

During the northeasterly monsoon (NEM) season between late autumn (October) and early spring (March), the main axis of the $\mathrm{KC}$ is usually close to the east coast of Taiwan, while cold, nutrient-rich, lowsalinity CCC waters, driven by the NEM, usually flow southward along the coast of the Chinese mainland into the northern or even central TS (Liu et al. 2000). The $\mathrm{KBC}$, which has similar hydrological characteristics to those of the $\mathrm{KC}$, flows through the Luzon Strait and northern South China Sea (SCS) and intrudes into the southeastern TS. The CCC and KBC usually meet near the central TS at the Yunchang Rise, where a thermohaline front consequently develops (Jan et al. 1998). During the southwesterly monsoon (SWM) season from late spring (May) to early autumn (September), the main axis of the $\mathrm{KC}$ generally moves away from the east coast of Taiwan, and the KBC is replaced by the warmer SCSSC, which flows northeastward into the southern or even central TS. At the same time, because of the SWM, the 


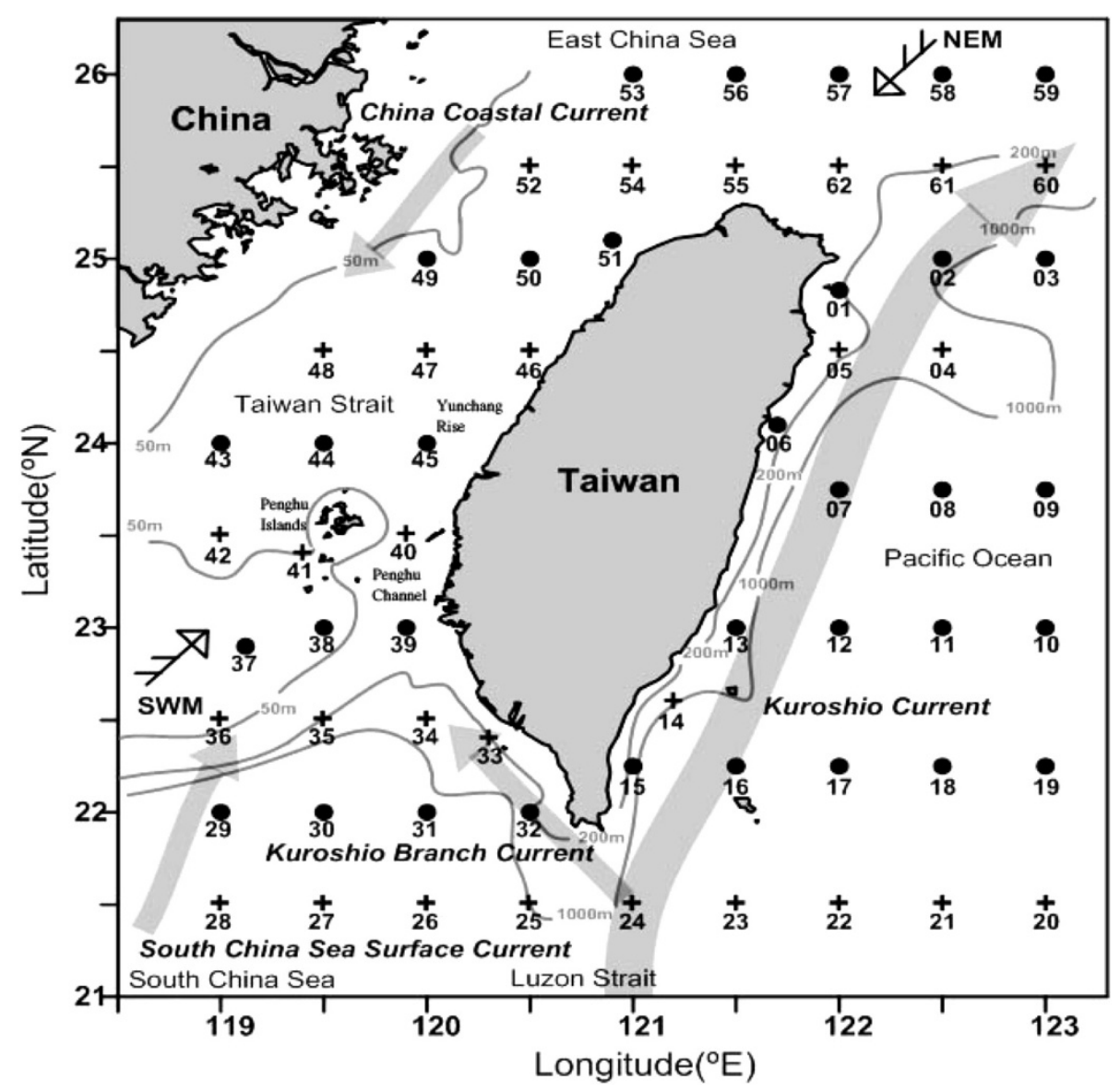

Figure 1 Sampling stations in waters around Taiwan in February and August 2004. Crosses, stations with CTD data only; solid circles, stations with both CTD and thaliacean samples; NEM, northeasterly monsoon; SWM, southwesterly monsoon.

CCC may only reach the northern TS or sometimes disappears altogether. All of these complex hydrological conditions in waters around Taiwan greatly affect the distribution patterns of marine zooplankton and other organisms (Lo et al. 2004, 2012; Hwang and Wong 2005; Hwang et al. 2006; Hsieh et al. 2011, 2012, 2013; Chou et al. 2012).

Pelagic tunicates are known to play a role in transferring energy from primary producers to higher trophic consumers in marine ecosystems (Seapy 1980; Larson et al. 1989; Crocker et al. 1991; Paffenhöfer and Gibson 1999). They form fine mucous filter nets to trap food organisms and can ingest tiny organic particles (i.e., particulate organic matter (POM), such as phytoplankton and remains of organisms) as their food sources from pelagic waters (Alldredge and Madin 1982; Crocker et al. 1991; Bone et al. 1997; Madin and Deibel 1998). They are also preyed upon by fish, seabirds, jellyfish, mollusks, and other animals (Seapy 1980; Larson et al. 1989), thus serving as part of the 'biological pump' in marine ecosystems. Furthermore, they produce big, fastdropping fecal pellets, which accelerate carbon transfer from upper to deeper waters (Fortier et al. 1994). High abundances of thaliaceans may be a result of their high asexual or sexual reproduction rates (Gibson and Paffenhöfer 2002), and for doliolids, the high asexual reproduction rate usually leads to rapid production in neritic regions (Deibel 1998). Gibson and Paffenhöfer (2002) proposed that the number and body size of gonozooids released from asexual reproduction of Dolioletta (Det.) gegenbauri were related to environmental conditions (e.g., phytoplankton concentration and temperature).

There have only been a few studies on thaliaceans in waters adjacent to Taiwan. Tew and Lo (2005) described seasonal changes and diel vertical migrations of three thaliacean species in coastal waters of southwestern Taiwan and proposed that the distribution patterns of these thaliaceans were related to reproduction, food availability, and hydrography. Zhang et al. (2003a, b) studied the distribution of thaliacean assemblages in the eastern TS in a subtropical bay off southwestern Taiwan. They found that the abundance of thaliaceans increased with increasing temperatures and phytoplankton concentrations. 
However, those studies were mostly limited to small areas of coastal waters.

The present study is a part of the Taiwan Cooperative Oceanic Fisheries Investigation (TaiCOFI) conducted by the Taiwan Fisheries Research Institute, which is the first large-scale $\left(21 \sim 26^{\circ} \mathrm{N}, 118 \sim 123^{\circ} \mathrm{E}\right)$ plankton and hydrographic survey carried out in waters around Taiwan to establish a long-term hydrographic and biological database and construct a numerical model for fishery forecasts. In the present study, we investigated spatial distributions of thaliacean assemblages during the NEM and SWM seasons in waters around Taiwan in order to elucidate possible influences of hydrological conditions driven by seasonal monsoons on distributional patterns of thaliaceans.

\section{Methods}

This survey was carried out in waters around Taiwan during Fishery Researcher I cruises in winter (February, NEM) and summer (August, SWM) of 2004 (Figure 1). At each station, temperature and salinity were obtained with a General Oceanics SeaBird CTD (SBE-911 Plus, Bellevue, WA, USA) from the surface to a depth of $200 \mathrm{~m}$ (or $10 \mathrm{~m}$ above the bottom at stations of $<200 \mathrm{~m}$ in depth). Seawater samples for chlorophyll (Chl) $a$ concentration measurements were collected with Go-Flo bottles (Miami, FL, USA) at six depths $(5,25,50,75$, 100 , and $150 \mathrm{~m}$ ), immediately filtered through Whatman GF/F filter paper (K.K., Tokyo, Japan) onboard, and then put in vials containing $10 \mathrm{ml}$ of $90 \%$ aqueous acetone for at least $24 \mathrm{~h}$ in a dark refrigerator for full extraction. In the laboratory, sample vials were shaken and centrifuged,

Table 1 Hydrographic variables (at 5-m depth) and average abundance, RA, and OR of the Thaliacea in 2004

\begin{tabular}{|c|c|c|c|c|c|c|}
\hline \multirow[t]{3}{*}{ Species } & \multicolumn{3}{|c|}{ Winter } & \multicolumn{3}{|c|}{ Summer } \\
\hline & Mean \pm SE & RA & OR & Mean \pm SE & $\mathrm{RA}$ & OR \\
\hline & (individuals $/ 1,000 \mathrm{~m}^{3}$ ) & (\%) & (\%) & (individuals $/ 1,000 \mathrm{~m}^{3}$ ) & (\%) & (\%) \\
\hline Thalia rhomboides & $454 \pm 160$ & 43.77 & 61.76 & $1,026 \pm 404$ & 32.13 & 82.35 \\
\hline Doliolum denticulatum & $313 \pm 96$ & 30.15 & 97.06 & $634 \pm 235$ & 19.84 & 97.06 \\
\hline Doliolum nationalis & 0 & 0 & 0 & $728 \pm 547$ & 22.81 & 14.71 \\
\hline Thalia orientalis & $77 \pm 29$ & 7.43 & 61.76 & $207 \pm 40^{* *}$ & 6.49 & 76.47 \\
\hline Pyrosoma verticillatum & $4 \pm 4$ & 0.35 & 2.94 & $232 \pm 161$ & 7.25 & 17.65 \\
\hline Thalia democratica & $37 \pm 11$ & 3.53 & 50.00 & $134 \pm 37^{*}$ & 4.21 & 79.41 \\
\hline Thalia cicar & $50 \pm 16$ & 4.80 & 61.76 & $50 \pm 12$ & 1.57 & 64.71 \\
\hline Weelia cylindrica & $4 \pm 4$ & 0.40 & 2.94 & $67 \pm 29^{*}$ & 2.09 & 38.24 \\
\hline Salpa fusiformis & $48 \pm 25$ & 4.65 & 44.12 & $12 \pm 8$ & 0.39 & 23.53 \\
\hline lasis zonaria & $14 \pm 9$ & 1.38 & 20.59 & 0 & 0 & 0 \\
\hline Salpa younti & 0 & 0 & 0 & $13 \pm 5^{*}$ & 0.40 & 26.47 \\
\hline Cyclosalpa sewelli & 0 & 0 & 0 & $10 \pm 4^{*}$ & 0.31 & 17.65 \\
\hline Dolioletta gegenbauri & $3 \pm 2$ & 0.30 & 5.88 & $1 \pm 1$ & 0.04 & 2.94 \\
\hline Brooksia rostrata & $2 \pm 2$ & 0.17 & 5.88 & $1 \pm 1$ & 0.03 & 2.94 \\
\hline Traustedtia multitenticulata & $2 \pm 2$ & 0.16 & 5.88 & $1 \pm 1$ & 0.02 & 2.94 \\
\hline Doliolina mulleri & $1 \pm 1$ & 0.08 & 5.88 & $1 \pm 1$ & 0.04 & 2.94 \\
\hline Pegea confoederata & 0 & 0 & 0 & $1 \pm 1$ & 0.02 & 2.94 \\
\hline Cyclosalpa affinis & 0 & 0 & 0 & $0.1 \pm 0.1$ & 0.004 & 2.94 \\
\hline Unidentified old nurse & $29 \pm 6$ & 2.79 & 61.76 & $74 \pm 14^{* *}$ & 2.33 & 85.29 \\
\hline Unidentified Thaliacea & $1 \pm 0.4$ & 0.05 & 5.88 & $1 \pm 1$ & 0.03 & 11.76 \\
\hline Total thaliaceans & $1,037 \pm 224$ & 100 & - & $3,193 \pm 705^{* *}$ & 100 & - \\
\hline Species number & $4.3 \pm 0.4$ & & & $5.7 \pm 0.4^{*}$ & & \\
\hline Species diversity & $0.9 \pm 0.1$ & & & $1.0 \pm 0.1$ & & \\
\hline Temperature $\left({ }^{\circ} \mathrm{C}\right)$ & $22.74 \pm 0.45$ & & & $28.96 \pm 0.17^{* * *}$ & & \\
\hline Salinity & $34.24 \pm 0.09$ & & & $34.14 \pm 0.04$ & & \\
\hline Chlorophyll a ( $\mu \mathrm{g} / \mathrm{L})$ & $0.12 \pm 0.04$ & & & $0.06 \pm 0.02$ & & \\
\hline
\end{tabular}

RA, relative abundance; OR, occurrence rate. Asterisks indicate a significant difference between seasons according to an ANOVA at ${ }^{*} p<0.05,{ }^{* *} p<0.01$, and ${ }^{* * *} p<0.001$. 


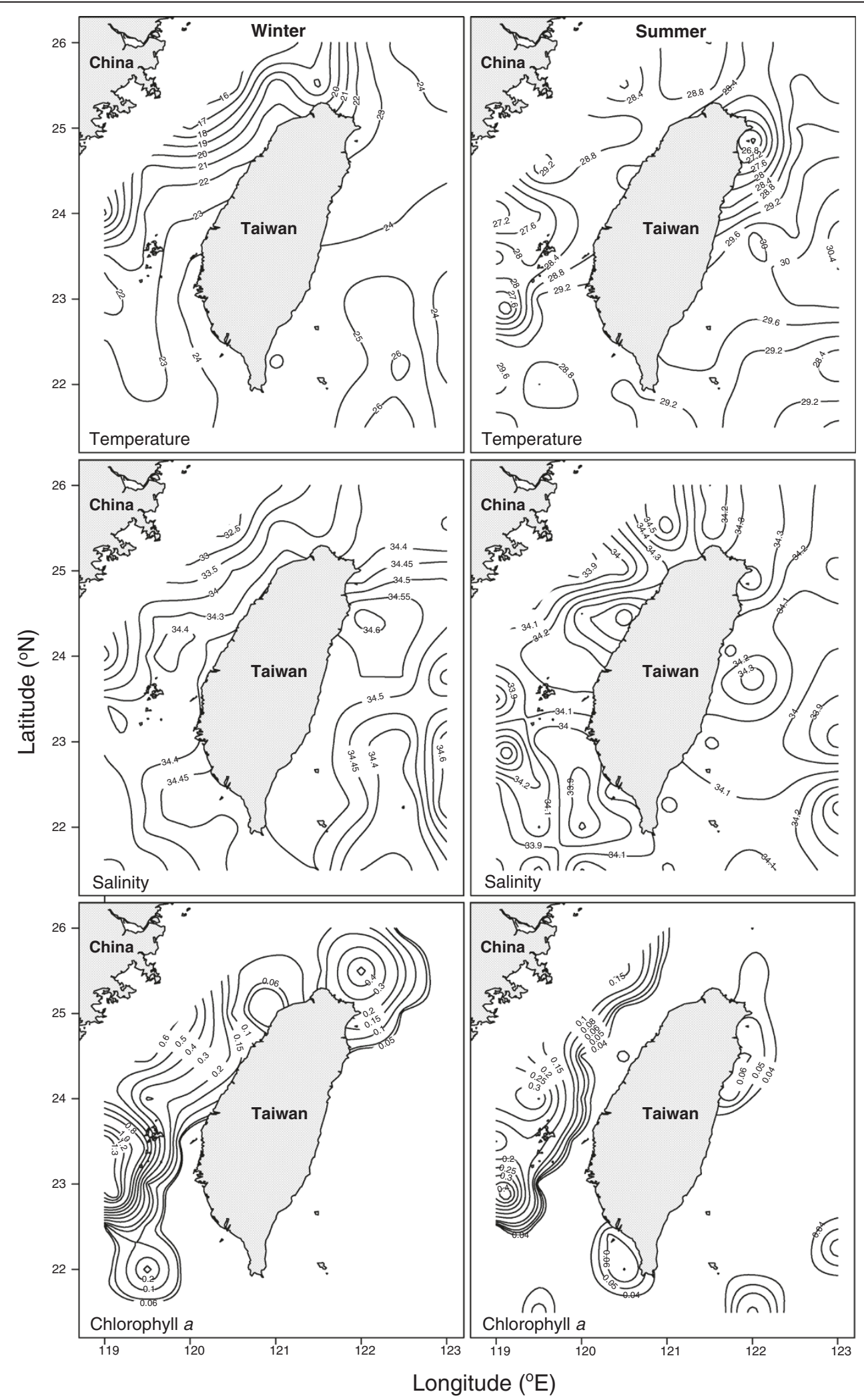

Figure 2 Sea temperature $\left({ }^{\circ} \mathrm{C}\right)$, salinity, and chlorophyll $a$ concentration $(\mu \mathrm{g} / \mathrm{L})$ contours of surface water (at 5-m depth). 


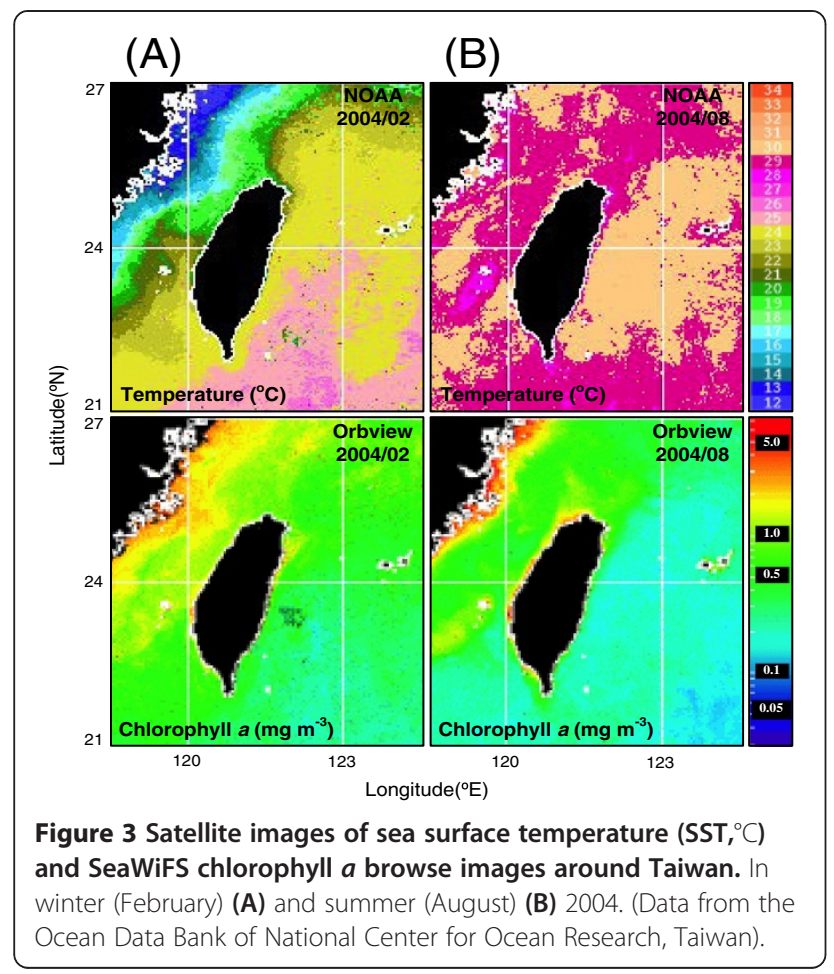

and the fluorescence was measured with a fluorescence spectrophotometer (Hitachi model F-2000, Tokyo, Japan) before and after acidification with 10\% hydrochloric acid. The amount of $\mathrm{Chl} a$ was then calculated using equations of Strickland and Parsons (1972).

Zooplankton samples were collected from 34 of the 62 hydrographic stations using an Ocean Research Institute (ORI; Tokyo, Japan) net with a mouth diameter of $1.6 \mathrm{~m}$ and a mesh size of $330 \mu \mathrm{m}$. A flowmeter (Hydro-Bios, Kiel, Schleswig-Holstein, Germany) was mounted at the center of the mouth opening to estimate the volume of filtered water. The net was towed vertically from $200 \mathrm{~m}$ (or $10 \mathrm{~m}$ above the bottom at stations of $<200 \mathrm{~m}$ in depth) to the surface at a speed of $1 \mathrm{~m} / \mathrm{s}$. After collection, all samples were immediately preserved onboard in $5 \% \sim 10 \%$ borax-buffered formalin seawater. In the laboratory, thaliaceans were identified and counted under a dissecting microscope (Askania SLG, Rathenow, Germany). Doliolids were identified to species level and to two life cycle stages: gonozooids and phorozooids. We did not use oozooid samples for this study because oozooids are unknown for most doliolid species (Godeaux et al. 1998). Salps were also identified to species level and two life stages (solitary and aggregate), and body sizes of gonozooids were measured from their buccal siphon to the atrial siphon (Godeaux 1998).

Abundances of thaliaceans were expressed as the number of individuals $/ 1,000 \mathrm{~m}^{3}$. A cluster analysis with a normalized Euclidean distance was used to distinguish hydrographic regions based on temperature and salinity data collected at $5 \sim 20 \mathrm{~m}$ in depth at each station. Shannon's diversity index (Shannon and Weaver 1963) was used to calculate the species diversity of thaliaceans. An analysis of variance (ANOVA) was used to test if biological and hydrographic variables significantly differed between seasons (NEM vs. SWM) and locations (oceanic vs. neritic). Multidimensional scaling (MDS) was used to analyze seasonal and spatial variations in the thaliacean assemblage structure. Indicator values of thaliacean species of station groups (water masses), based on the equation of Dufrene and Legendre (1997), were calculated to find possible indicator species and their preferred hydrographic conditions. Multiple regressions with a forward stepwise method were used to analyze relationships between thaliacean abundances and hydrographic variables. Cluster dendograms of the

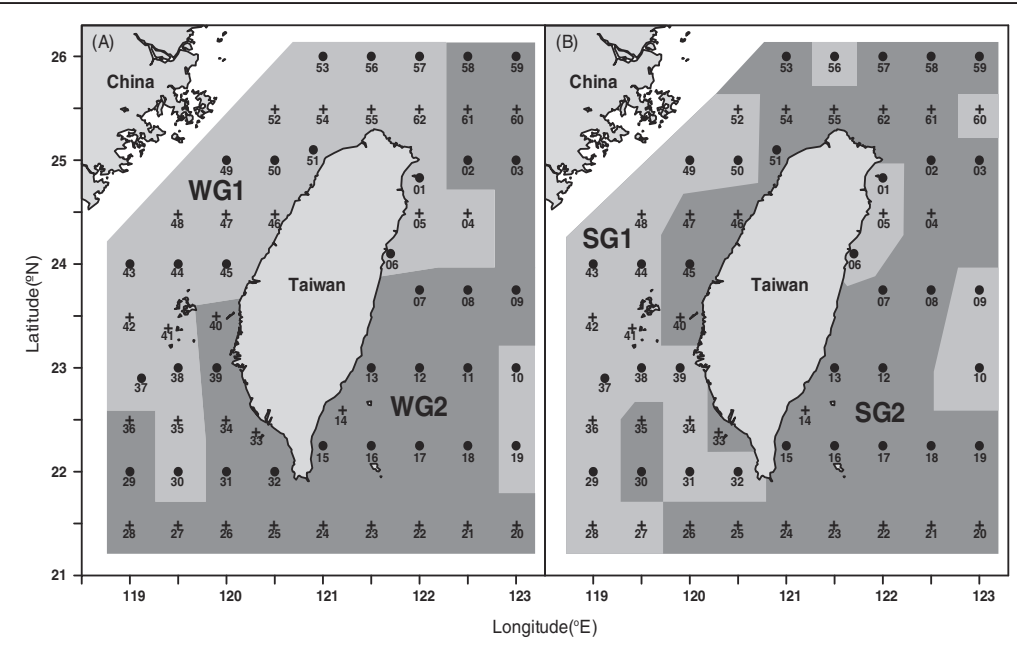

Figure 4 Station groups delineated from results of a cluster analysis based on hydrographic data. In winter (A) and summer (B) 2004. (Temperature and salinity at a depth of $1 \sim 20 \mathrm{~m}$ ). 
Table 2 Indicator values of thaliacean species and hydrographic characters of different station groups (from Figure 4)

\begin{tabular}{|c|c|c|}
\hline $\begin{array}{l}\text { Station group/ } \\
\text { species }\end{array}$ & Ind. Val. & $\begin{array}{l}\text { Hydrographic characters } \\
\text { (at a depth of } 5 \mathrm{~m} \text {, mean } \pm \mathrm{SE} \text { ) }\end{array}$ \\
\hline \multicolumn{3}{|l|}{ Winter } \\
\hline WG1 & & T $20.9 \pm 0.7$, S $34.0 \pm 0.7$, C $0.3 \pm 0.1$ \\
\hline $\begin{array}{l}\text { Doliolum } \\
\text { denticulatum }\end{array}$ & 68.49 & \\
\hline WG2 & & T $24.4 \pm 0.2$, S $34.4 \pm 0.03, C<0.05$ \\
\hline Thalia orientalis & 96.54 & \\
\hline Thalia cicar & 66.57 & \\
\hline Thalia democratica & 65.13 & \\
\hline Thalia rhomboides & 60.40 & \\
\hline \multicolumn{3}{|l|}{ Summer } \\
\hline $\mathrm{SG} 1$ & & $T 28.7 \pm 0.3, S 34.0 \pm 0.1, C 0.07 \pm 0.03$ \\
\hline $\begin{array}{l}\text { Doliolum } \\
\text { denticulatum }\end{array}$ & 72.73 & \\
\hline SG2 & & T $29.1 \pm 0.1$, S $34.2 \pm 0.03, C<0.05$ \\
\hline Thalia democratica & 57.24 & \\
\hline Thalia orientalis & 51.80 & \\
\hline
\end{tabular}

Ind. Val., indicator value (only those with an Ind. Val. of $>50$ are shown); $T$, temperature $\left({ }^{\circ} \mathrm{C}\right) ; \mathrm{S}$, salinity; $\mathrm{C}$, chlorophyll $a(\mu \mathrm{g} / \mathrm{L})$.
Bray-Curtis similarity matrix were used to evaluate the similarity of body-size frequency of the gonozooid stage of Doliolum denticulatum among stations, and the distribution in abundance of each body size group was then delineated on a map to visualize its relationship with hydrographic conditions.

\section{Results}

\section{Hydrographic conditions}

Hydrographic features exhibited significant seasonal changes in waters around Taiwan, with higher temperatures and lower Chl $a$ concentrations in the summer SWM than in the winter NEM (Table 1). Hydrographic characteristics during both monsoon seasons showed clear northwest-southeast gradients in the TS, particularly in winter, when the CCC with cold, low-salinity water and high Chl a concentrations dominated the northwestern part of the TS adjacent to the Chinese coast (Figure 2). In summer, the SCSSC comprising warm, lower-salinity waters intrudes into the southern or central TS when the CCC retreats northward. Furthermore, owing to three consecutive typhoons in the study area during the summer sampling period of 2004, distribution patterns of temperature and salinity became more irregular, but the distribution pattern of Chl $a$ concentrations in the TS was still similar to that in

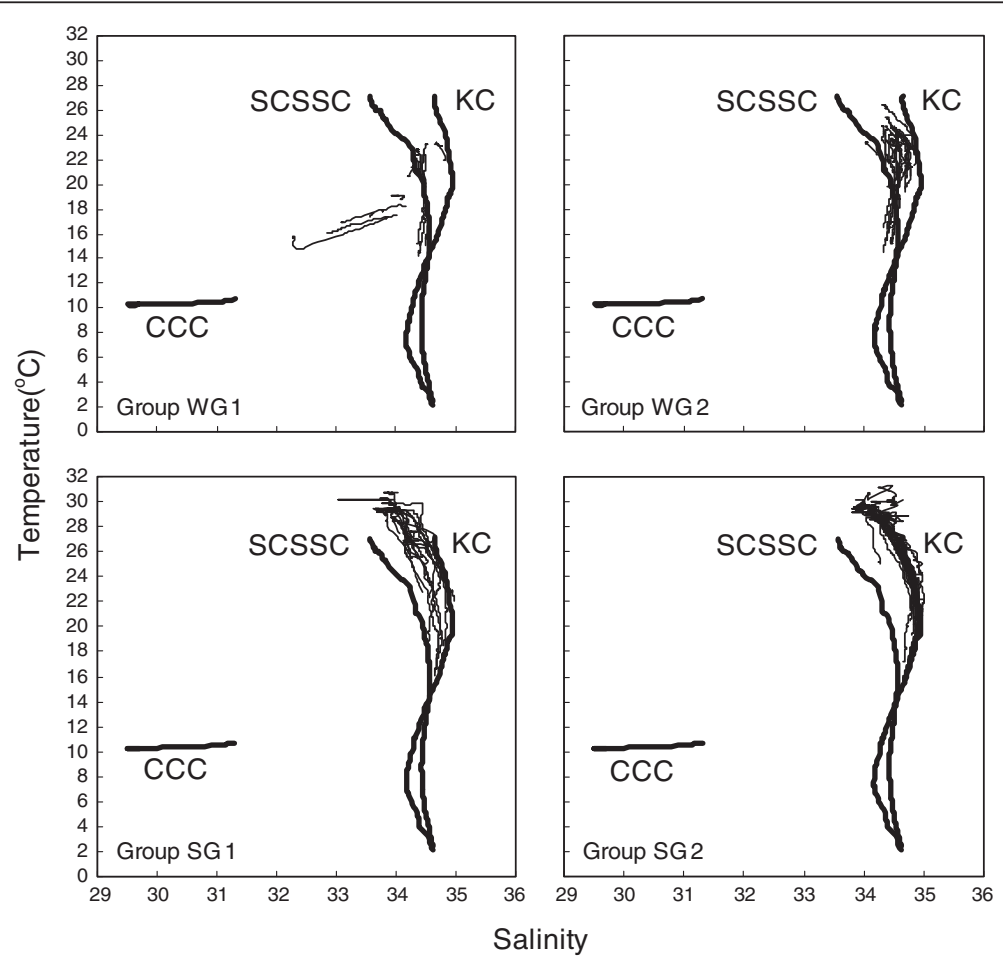

Figure 5 Temperature-salinity diagrams of different hydrographic station groups in winter and summer 2004 (see Figure 4). 


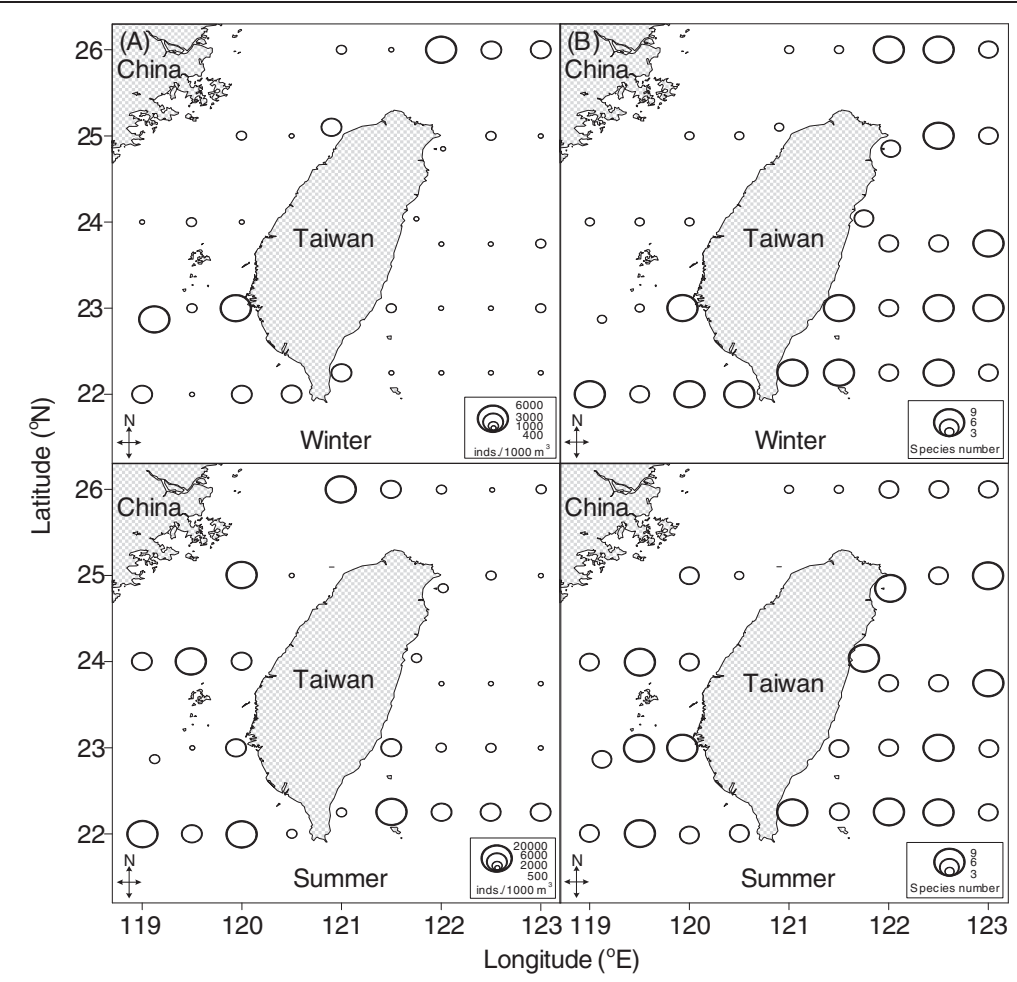

Figure 6 Distributions of abundances (A) and species numbers (B) of Thaliacea in winter and summer 2004.

winter (Figure 2). These distribution patterns were also confirmed by satellite images of sea surface temperatures (SSTs) and SeaWiFS Chl $a$ during our sampling periods (Figure 3).

According to results of a cluster analysis based on hydrographic data, two hydrographic station groups were distinguished in each season: WG1 and WG2 in winter and SG1 and SG2 in summer (Figure 4). In winter, WG1 included 16 sampling stations (Figure 4A) in waters of western and northwestern Taiwan that may have been influenced by the CCC, which were characterized by lower temperatures and salinities and higher $\mathrm{Chl}$ $a$ concentrations than in KC and SCSSC waters (Table 2, Figure 5). WG2 comprised 18 sampling stations located in waters east and southwest of Taiwan in which the $\mathrm{KBC}$ usually prevailed with higher temperatures and salinities but lower Chl $a$ concentrations. The distribution of station groups in summer was a little chaotic (Figure 4B), but their distribution pattern could also be separated into two station groups. SG1 mostly comprised stations in the TS and were mainly influenced by the SCSSC, although some isolated stations were scattered in eastern and southwestern waters of Taiwan. SG2 comprised stations mainly located in waters east of Taiwan dominated by the KC (Figure 5). Between the two station groups, lower temperatures and salinities and higher Chl $a$ concentrations were observed in SG1 (Table 2), and variations in temperature and salinity in both station groups in summer were less than those in winter (Table 2).

\section{Composition of the thaliacean assemblage}

In total, 18 thaliacean species belonging to 3 orders, 3 families, and 12 genera were identified in the present study (Table 1). Species compositions of thaliaceans were nearly similar between seasons, but abundances (ANOVA, $F=8.113, \quad p<0.01$ ) and species numbers (ANOVA, $F=6.400, p<0.05$ ) were significantly higher in summer than in winter. During the winter NEM, nine salpid, three doliolid, and one pyrosomatid species were recognized, respectively constituting $69.1 \%, 30.5 \%$, and $0.4 \%$ of the total catch of thaliaceans. Thalia rhomboides and $D$. denticulatum were the two predominant species, together comprising $73.9 \%$ of the total thaliacean abundance (Table 1). During the summer SWM, 12 salpid, 4 doliolid, and 1 pyrosomid species were recorded, respectively contributing $50.0 \%, 42.7 \%$, and $7.3 \%$ to the total thaliacean number. T. rhomboides was the most dominant salpid species comprising $32.1 \%$ of the total abundance, while Doliolum nationalis and D. denticulatum respectively constituted $22.8 \%$ and $19.8 \%$ of the overall abundance (Table 1).

Spatial distribution patterns of abundance and species number of thaliaceans were similar between seasons (Figure 6). Abundances of thaliaceans were higher in northeastern and southwestern waters of Taiwan in 
winter and in the TS and waters south of Taiwan in summer (Figure 6A). Species numbers were always higher in waters east and south of Taiwan than in waters northwest of Taiwan in both seasons (Figure 6B). Comparing the average abundance of thaliaceans between oceanic $(\geq 200 \mathrm{~m})$ and neritic $(<200 \mathrm{~m})$ waters around Taiwan (Table 3), five species of the order Salpida, $T$. rhomboides, Thalia orientalis, Thalia democratica, Salpa fusiformis, and Salpa younti, were considered to be oceanic species. In contrast, all species of the order Doliolida were regarded as shallow-water species with

Table 3 Average abundances of thaliacean species in oceanic and neritic waters around Taiwan during the study periods

\begin{tabular}{|c|c|c|}
\hline Species & $\begin{array}{c}\text { Oceanic } \\
\text { (depth } \geq 200 \mathrm{~m}, \\
\text { individuals } / 1,000 \mathrm{~m}^{3} \text { ) }\end{array}$ & $\begin{array}{c}\text { Neritic } \\
(\text { depth }<200 \mathrm{~m}, \\
\text { individuals } / 1,000 \mathrm{~m}^{3} \text { ) }\end{array}$ \\
\hline
\end{tabular}

\begin{tabular}{|c|c|c|}
\hline \multicolumn{3}{|l|}{ Doliolida } \\
\hline $\begin{array}{l}\text { Doliolum } \\
\text { denticulatum }\end{array}$ & $151 \pm 27$ & $933 \pm 288^{* *}$ \\
\hline $\begin{array}{l}\text { Dolioletta } \\
\text { gegenbauri }\end{array}$ & 0 & $5 \pm 3^{*}$ \\
\hline Doliolina mulleri & 0 & $2 \pm 2^{*}$ \\
\hline $\begin{array}{l}\text { Doliolum } \\
\text { nationalis }\end{array}$ & 0 & $885 \pm 662^{* *}$ \\
\hline \multicolumn{3}{|l|}{ Salpida } \\
\hline $\begin{array}{l}\text { Brooksia } \\
\text { rostrata }\end{array}$ & $2 \pm 2$ & 0 \\
\hline $\begin{array}{l}\text { Cyclosalpa } \\
\text { affinis }\end{array}$ & $0.1 \pm 0.1$ & 0 \\
\hline $\begin{array}{l}\text { Cyclosalpa } \\
\text { sewelli }\end{array}$ & $7 \pm 3$ & $2 \pm 2$ \\
\hline lasis zonaria & $5 \pm 3$ & $11 \pm 11$ \\
\hline $\begin{array}{l}\text { Pegea } \\
\text { confoederata }\end{array}$ & 0 & $1 \pm 1$ \\
\hline Salpa fusiformis & $46 \pm 22$ & $7 \pm 4^{* *}$ \\
\hline Salpa younti & $11 \pm 4$ & $0^{* *}$ \\
\hline $\begin{array}{l}\text { Thalia } \\
\text { rhomboides }\end{array}$ & $960 \pm 347$ & $426 \pm 183^{*}$ \\
\hline Thalia orientalis & $167 \pm 33$ & $107 \pm 41^{* * *}$ \\
\hline Thalia cicar & $44 \pm 11$ & $58 \pm 19$ \\
\hline $\begin{array}{l}\text { Thalia } \\
\text { democratica }\end{array}$ & $122 \pm 32$ & $34 \pm 10^{* * *}$ \\
\hline $\begin{array}{l}\text { Traustedtia } \\
\text { multitenticulata }\end{array}$ & $2 \pm 1$ & 0 \\
\hline $\begin{array}{l}\text { Weelia } \\
\text { cylindrica }\end{array}$ & $26 \pm 11$ & $49 \pm 33$ \\
\hline \multicolumn{3}{|l|}{ Pyrosomatida } \\
\hline $\begin{array}{l}\text { Pyrosoma } \\
\text { verticillatum }\end{array}$ & $137 \pm 132$ & $90 \pm 59$ \\
\hline
\end{tabular}

Asterisks indicate significant differences according to an ANOVA at ${ }^{*} p<0.05$, ${ }^{* *} p<0.01$, and ${ }^{* * *} p<0.01$. Oceanic stations: $1,2,3,6,7,8,9,10,11,12,13,15$, $16,17,18,19,29,30,31$, and 32 . Neritic stations: $37,38,39,43,44,45,49,50$, $51,53,56,57,58$, and 59 . higher indicator values in shelf waters off western and northern Taiwan. Results of the MDS analysis indicated that thaliacean assemblages showed some variations between seasons and areas (Figure 7), particularly the neritic assemblage, which exhibited larger variations among stations than did the oceanic assemblage in both seasons.

\section{Indicator species of the Thaliacea and associated hydrographic conditions}

The indicator species (with indicator values of $>50$ ) of thaliaceans in different water masses in both seasons are shown in Table 2 . In winter, $D$. denticulatum was the only species with a higher indicator value (68.5) in WG1, while $T$. orientalis, Thalia cicar, $T$. democratica, and $T$. rhomboides showed higher values $(>60.4)$ in WG2. In summer, $D$. denticulatum exhibited higher indicator values (72.7) in SG1, and two Thalia species, $T$. democratica and T. orientalis, had higher values in SG2. By analyzing indicator values of thaliaceans and hydrographic characteristics of each station group, we deduced that $D$. denticulatum might prefer waters of lower temperatures and salinities and higher $\mathrm{Chl} a$ concentrations, while salps favor waters of higher temperatures and salinities.

Results of the multiple regression analysis (Table 4) showed that the abundance of $D$. denticulatum was positively correlated with the Chl $a$ concentration $(p<0.05)$, while abundances of $T$. rhomboides $(p<0.05), T$. orientalis $(p<0.01)$, and $T$. democratica $(p<0.001)$ were negatively related to seawater temperature, and that of $T$. orientalis was negatively correlated with $\mathrm{Chl} a$ concentrations $(p<0.05)$. Pyrosomid species showed no correlations with any environmental variables. These results implied that salpid and doliolid species were influenced

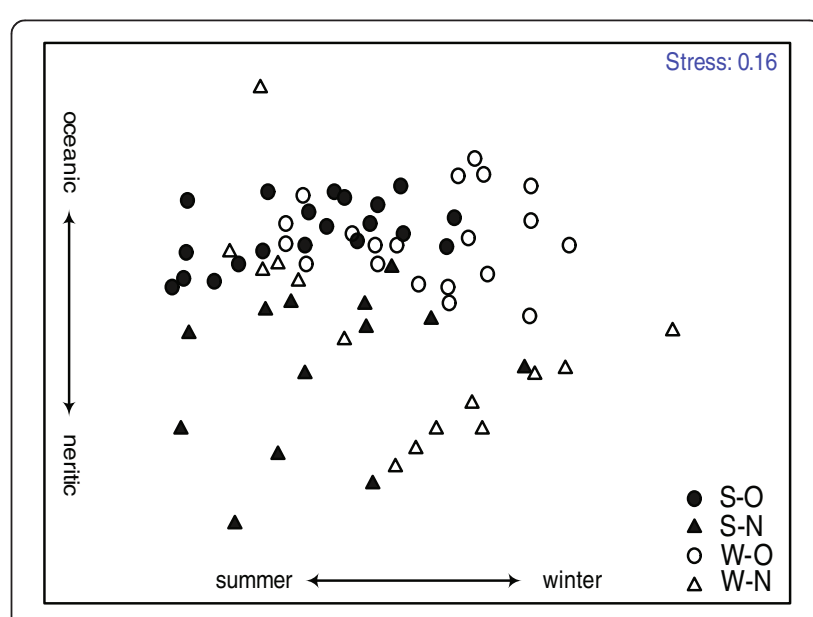

Figure $7 \mathrm{MDS}$ analyses of the thaliacean community in waters around Taiwan in 2004. S, summer; W, winter; O, oceanic; $\mathrm{N}$, neritic. 
Table 4 Results of a forward stepwise regression and partial correlation coefficient $(R)$

\begin{tabular}{|c|c|c|c|c|}
\hline Species & $R$ for $T$ & $R$ for $S$ & $R$ for $C$ & Predictive equation \\
\hline Thalia rhomboides (TR) & $0.377^{*}$ & 0.214 & -0.233 & $\mathrm{TR}=6.13 T-42.41$ \\
\hline Doliolum denticulatum (DD) & -0.009 & -0.101 & $0.277^{*}$ & $\mathrm{DD}=3.85 \mathrm{C}+16.14$ \\
\hline Doliolum nationalis & 0.162 & 0.049 & 0.160 & ns \\
\hline Thalia orientalis (TO) & $0.483^{* *}$ & 0.167 & $-0.432^{*}$ & $\mathrm{TO}=6.00 \mathrm{~T}-4.98 \mathrm{C}+0.89$ \\
\hline Pyrosoma verticillatum & 0.218 & -0.085 & 0.012 & ns \\
\hline Thalia democratica (TD) & $0.526^{* * *}$ & 0.098 & -0.389 & $\mathrm{TD}=7.07 T+24.76$ \\
\hline Total thaliaceans (TT) & $0.278^{* *}$ & 0.042 & 0.090 & $\Pi=4.28 T+3.29$ \\
\hline Species number (SN) & $0.501^{* *}$ & 0.222 & $-0.415^{*}$ & $\mathrm{SN}=1.30 T-0.90 \mathrm{C}-3.43$ \\
\hline Species diversity (SD) & 0.380 & 0.260 & $-0.433^{*}$ & $S D=-0.75 C-5.27$ \\
\hline
\end{tabular}

Relationships of abundances of the six predominant thaliacean species (with a relative abundance of 93\%) and environmental variables in waters around Taiwan in winter and summer 2004 are evaluated; ${ }^{*} p<0.05,{ }^{* *} p<0.01,{ }^{* * *} p<0.001 ;$ ns, not significant; $T$, temperature; $S$, salinity; $C$, chlorophyll $a$.

by different hydrographic factors, which resulted in distinct distribution patterns in our study area.

\section{Distribution patterns in generations and size fractions of the Thaliacea}

During our sampling period, $D$. denticulatum and $D$. nationalis showed higher abundances of phorozooids, and in summer, the latter was devoid of gonozooids; on the other hand, most salpid species had higher percentages of aggregate zooids, but $T$. democratica showed a little higher abundance of solitary zooids than aggregate zooids during both seasons (Table 5). Comparing spatial patterns in abundances and generations of the two predominant thaliaceans, $T$. rhomboides and $D$. denticulatum, in winter and summer, it can be seen that T. rhomboides was mainly distributed in waters off northeastern, eastern, and southwestern Taiwan, it was scarce in waters off northeastern Taiwan in both seasons, and its aggregated zooids showed higher percentages at most stations, especially in southern warm waters in summer (Figure 8A). However, D. denticulatum showed higher abundances in northern and western waters of Taiwan and had higher percentages of phorozooids at most stations (Figure 8B).

According to the cluster dendogram, based on the body-size frequency of the gonozooid stage of $D$. denticulatum, three station groups could be distinguished in each season, and each group seemed to display distinct distribution patterns. In winter (Figure 9), station group I (G-I), with gonozooids of body lengths of $3.0 \sim$ $3.5 \mathrm{~mm}$, contained only two stations in waters east of Taiwan with relatively low abundances; gonozooids in station group II (G-II) were mostly of median sizes $(2.5 \sim 3.0 \mathrm{~mm})$ and were mainly distributed in waters northwest of Taiwan, while group III (G-III) mainly comprised gonozooids of small sizes $(1.5 \sim 2.0 \mathrm{~mm})$ and was widely distributed in waters around Taiwan with higher abundances in the northeast to southwest. In summer (Figure 10), G-I contained only one station in coastal waters east of Taiwan with gonozooids of larger body sizes $(3.5 \sim 4.0 \mathrm{~mm})$ and low abundances, G-II comprised gonozooids of body sizes of $2.0 \sim 2.5 \mathrm{~mm}$ and with higher abundances in northwestern waters, while G-III was mostly comprised of gonozooids of small body sizes $(1.5 \sim 2.0 \mathrm{~mm})$ with higher abundances in waters northeast and southwest of Taiwan.

Table 5 Average abundances and percentage generation of the six predominant thaliacean species in 2004

\begin{tabular}{|c|c|c|c|c|c|}
\hline \multirow[t]{2}{*}{ Species } & & \multicolumn{2}{|l|}{ Winter } & \multicolumn{2}{|l|}{ Summer } \\
\hline & & $\begin{array}{c}\text { Mean } \pm \text { SE } \\
\text { (individuals/ } \\
1,000 \mathrm{~m}^{3} \text { ) }\end{array}$ & PG & $\begin{array}{c}\text { Mean } \pm \text { SE } \\
\text { (individuals/ } \\
1,000 \mathrm{~m}^{3} \text { ) }\end{array}$ & PG \\
\hline \multicolumn{6}{|l|}{ Salpida } \\
\hline \multirow{2}{*}{$\begin{array}{l}\text { Thalia } \\
\text { rhomboides }\end{array}$} & S & $66 \pm 20$ & 14.6 & $127 \pm 49$ & 12.3 \\
\hline & $A$ & $388 \pm 146$ & 85.4 & $900 \pm 357$ & 87.7 \\
\hline \multirow{2}{*}{$\begin{array}{l}\text { Thalia } \\
\text { orientalis }\end{array}$} & $S$ & $19 \pm 5$ & 24.8 & $28 \pm 9$ & 13.5 \\
\hline & A & $58 \pm 25$ & 75.2 & $179 \pm 34$ & 86.5 \\
\hline \multirow[t]{2}{*}{ Thalia cicar } & S & $1 \pm 7$ & 25.7 & - & - \\
\hline & $A$ & $37 \pm 11$ & 74.3 & - & - \\
\hline \multirow{2}{*}{$\begin{array}{l}\text { Thalia } \\
\text { democratica }\end{array}$} & S & $20 \pm 6$ & 54.7 & $71 \pm 17$ & 53.1 \\
\hline & $A$ & $17 \pm 8$ & 45.3 & $63 \pm 25$ & 46.9 \\
\hline \multirow{2}{*}{$\begin{array}{l}\text { Salpa } \\
\text { fusiformis }\end{array}$} & S & $7 \pm 5$ & 14.2 & - & - \\
\hline & $A$ & $41 \pm 20$ & 85.8 & - & - \\
\hline \multicolumn{6}{|l|}{ Doliolida } \\
\hline \multirow{2}{*}{$\begin{array}{l}\text { Doliolum } \\
\text { denticulatum }\end{array}$} & G & $71 \pm 19$ & 22.8 & $119 \pm 41$ & 18.7 \\
\hline & $P$ & $241 \pm 89$ & 77.2 & $515 \pm 210$ & 81.3 \\
\hline \multirow{2}{*}{$\begin{array}{l}\text { Doliolum } \\
\text { nationalis }\end{array}$} & G & ns & ns & ns & ns \\
\hline & $P$ & ns & ns & $728 \pm 546$ & 100.0 \\
\hline \multicolumn{6}{|l|}{ Pyrosomatida } \\
\hline $\begin{array}{l}\text { Pyrosoma } \\
\text { verticillatum }\end{array}$ & Z & ns & ns & $232 \pm 161$ & \\
\hline
\end{tabular}

PG, percentage generation, $S$, solitary zooid; A, aggregate zooid; G, gonozooid; $P$, phorozooid; $Z$, zooid; ns, no sample; -, not dominant in this season. 


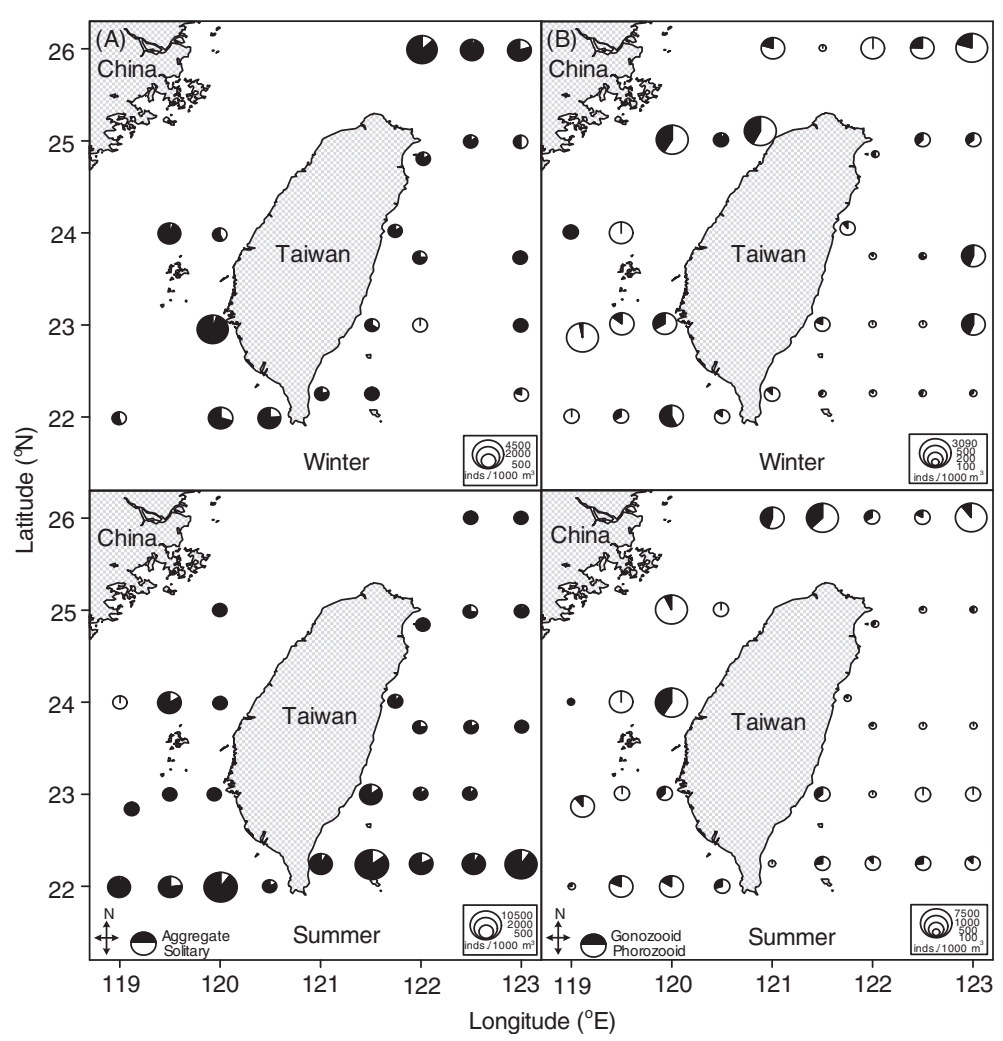

Figure 8 Spatial distributions of abundances and generations of the two predominant thaliacean species in winter and summer 2004. (A) T. rhomboides and (B) D. denticulatum.

\section{Discussion}

\section{Hydrographic environments}

The seasonal monsoon system and bathymetric topography are the two main physical parameters affecting spatiotemporal variations in water masses and determine through-flow transport (Jan et al. 2002, 2006). In winter, the CCC extended south into the central TS, as evidenced by lower temperatures and salinities from southeast to northwest. Meanwhile, in the southeastern TS, a water tongue of relatively high temperature and salinity stretched northward through the Penghu Channel, signaling penetration of the $\mathrm{KBC}$ into the southeastern TS (Figures 2 and 3). However, in winter, this northerly extension of the $\mathrm{KBC}$ was largely inhibited by the southerly moving CCC near the Penghu Channel, which consequently reduced the transport of plankton from SCS and KBC waters to the northern TS. On the contrary, when the SWM prevailed, warm, lower-salinity waters originating from the SCS were widely distributed over the entire TS. The SCSSC replaced the KBC and dominated summer oceanic conditions in the TS. Compared to waters west of Taiwan, the hydrographic situation in waters east of Taiwan was much simpler and was dominated by the warm and highly saline $\mathrm{KC}$ year-round. These hydrographic conditions in waters surrounding Taiwan are consistent with previous studies on the KC and East China Sea (ECS) (Wang and Chern 1988; Chern et al. 1990; Liu et al. 1992) and on the TS (Jan et al. 2002, 2006).

In the present study, we also noted that lower temperatures and higher salinities in the western TS, especially in waters southwest of the Penghu Islands, indicated the formation of topographic upwelling due to the Yunchang Rise (YR) (Figure 2). According to Jan et al. (1994), when the KBC and SCSSC impinge on the YR, surface and bottom waters may flow in different directions upstream of it. The former flows over the YR and moves along the eastern side of the TS, while the latter is obstructed by the YR and turns northwestward along local isobaths into the northwestern TS. However, bottom water rises near the Penghu Islands and forms a cyclonic ring characterized by upwelling of cold water from greater depths to enrich the upper waters with nutrients. Our study further confirmed this phenomenon. High levels of nutrients in our study area were also reported by Chung et al. (2001).

\section{Factors affecting thaliacean distributions}

Seawater temperature is an imperative factor affecting the distribution of salps (Brandon et al. 2004). During 


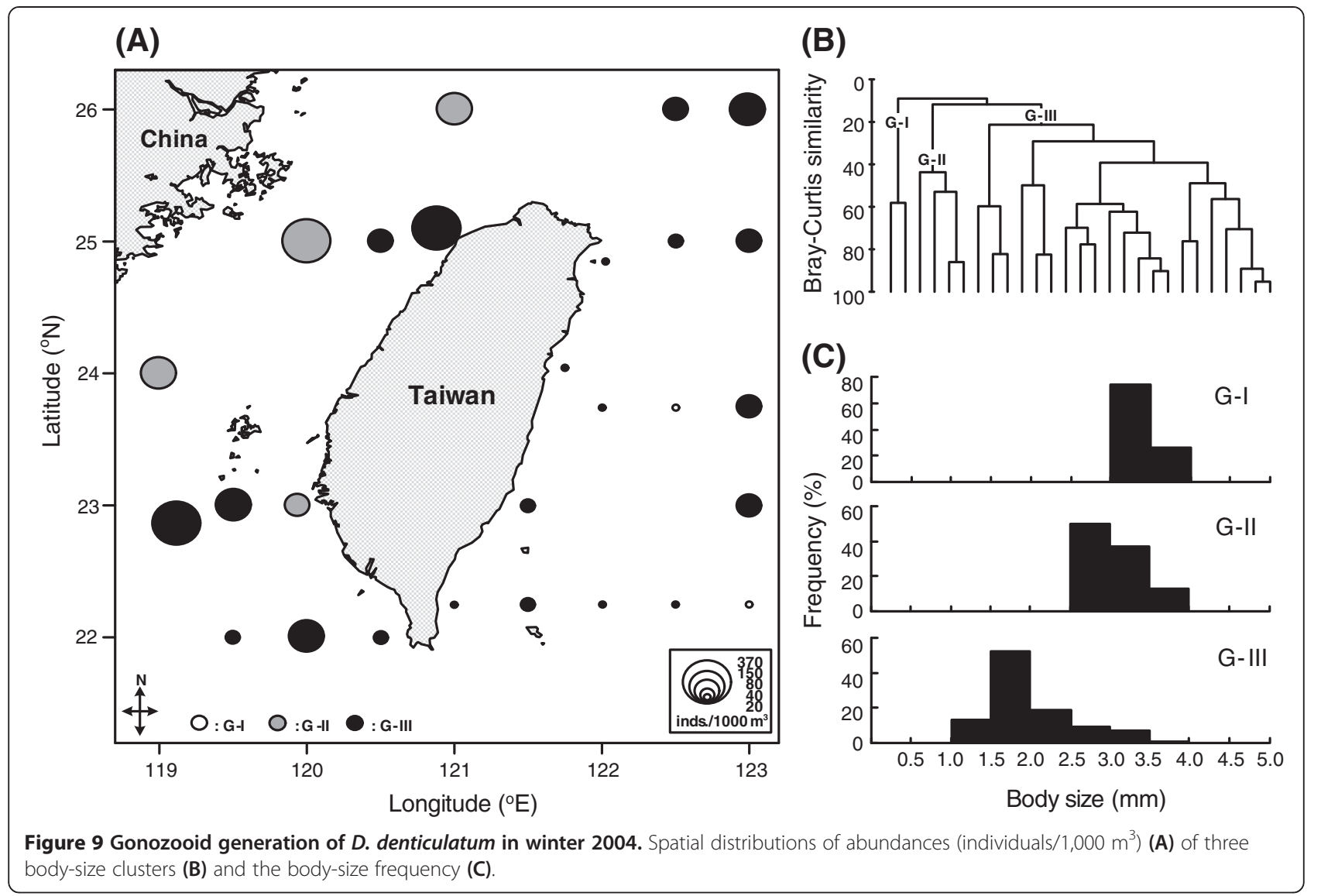

the warm period in the Southern Ocean, asexual reproduction prevails in salps, where a large number of aggregate zooids are budded (Daponte et al. 2001; Kawaguchi et al. 2004). In our study, most salp species showed higher abundances in the aggregate stage than in the solitary stage (Table 5). For example, T. rhomboides dominated in the aggregate stage and was mainly distributed in waters east and southwest of Taiwan where the KC and SCSSC respectively prevailed yearround (Figure 8). The oligotrophic $\mathrm{KC}$ and SCSSC, usually with water temperatures ranging $24^{\circ} \mathrm{C} \sim 31^{\circ} \mathrm{C}$ (Figure 2), likely provided a warm environment suitable for T. rhomboides and most other salp species to perform massive asexual reproduction. A similar phenomenon was also observed by Nishikawa et al. (1995) when Salpa thompsoni became greatly abundant in nutrient-poor oceanic waters near South Shetland Islands in summer and by Kremer and Madin (1992) that salps were well adapted to an oligotrophic environment.

In contrast, doliolids feed on food particles of a wide size range with their mucous filter net. They, therefore, prefer food-rich shelf and coastal waters where the environment is probably more beneficial for their reproduction (Gibson and Paffenhöfer 2002; Deibel and Paffenhöfer 2009). Gibson and Paffenhöfer (2002) observed that the release rate of gonozooids of Det. gegenbauri increased with suitable water temperature when food concentrations increased from 7 to $160 \mu \mathrm{g} \mathrm{C/L}$. In our study, doliolids, with higher ratios of phorozooids, were mainly distributed in northern and northwestern waters of Taiwan with the usual dominance of lower-salinity and nutrient-rich CCC and East China Sea shelf waters. Similarly, doliolids also frequently dominated nutrient-rich shelf waters southeast of the USA (Paffenhöfer et al. 1987). They were usually scarce in waters east of Taiwan in our study, probably due to their soft bodies and weak swimming abilities, not being adapted to the higher current velocities and turbulent waters of the $\mathrm{KC}$.

Doliolids generally have lower growth rates than salps (Deibel 1982). The occurrence of a high biomass of doliolids results from their vigorous asexual reproduction that is influenced by various environmental conditions, such as temperature (Deibel and Paffenhöfer 2009), food, and physical actions (Gibson and Paffenhöfer 2002). For instance, Gibson and Paffenhöfer (2002) found that in coastal waters off the southeastern USA, phorozooids of Det. gegenbauri showed a lower reproduction rate but produced gonozooids of large body sizes that were less numerous at lower phytoplankton concentrations. However, at higher food concentrations, its phorozooids engaged in 


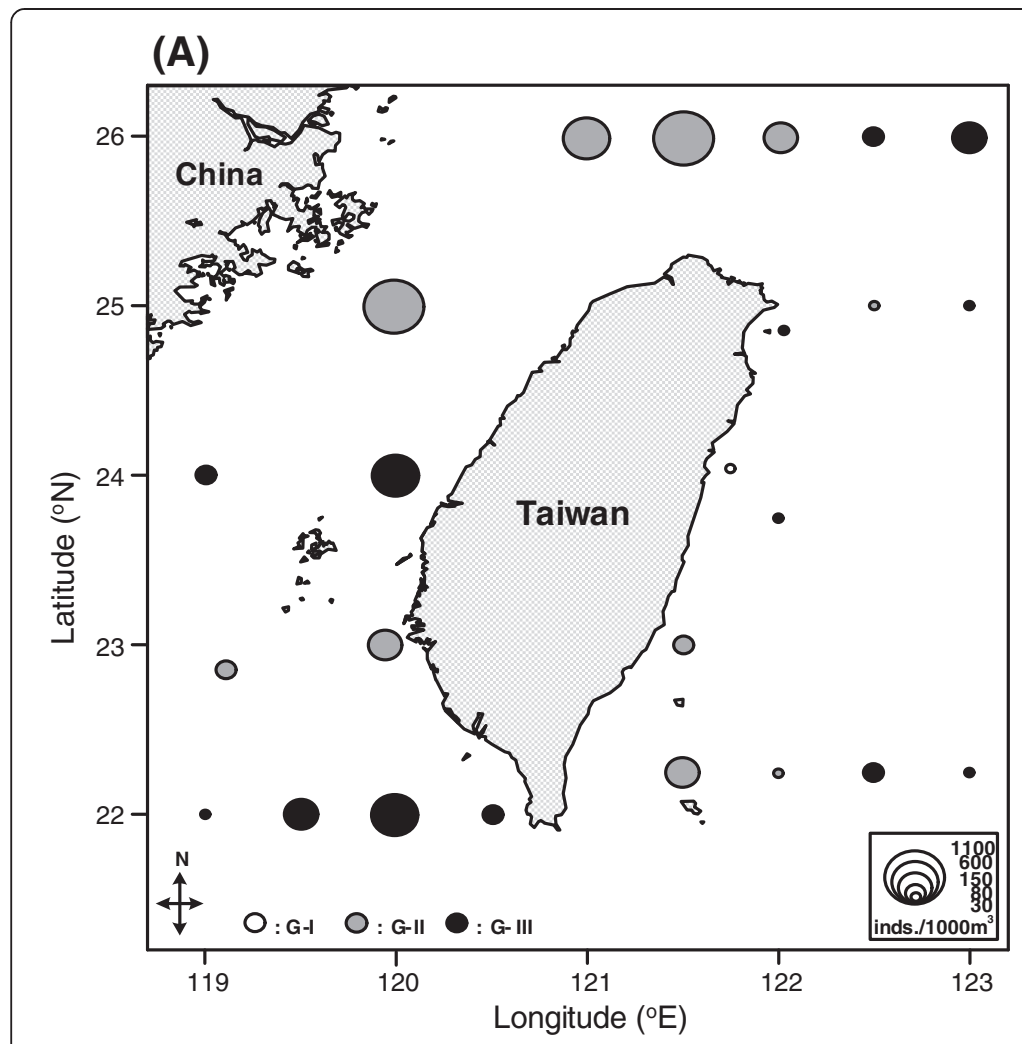

(B)

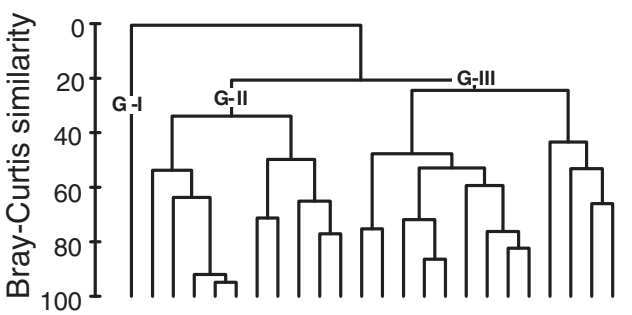

\section{(C)}

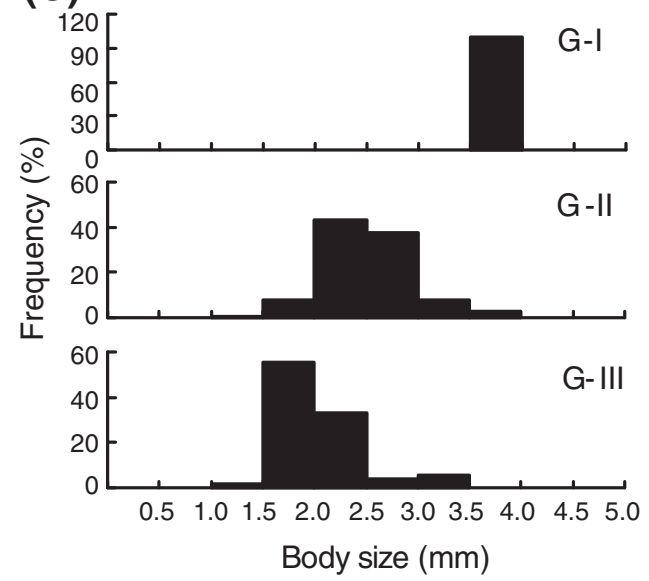

Figure 10 Gonozooid generation of $\boldsymbol{D}$. denticulatum in summer 2004. Spatial distributions of abundances (individuals/1,000 $\left.\mathrm{m}^{3}\right)(\mathbf{A})$ of three body-size clusters (B) and the body-size frequency (C).

asexual reproduction in large quantities within short periods of time and produced large-size gonozooids, implying that Det. gegenbauri can produce gonozooids of larger size $(2.98$ and $3.15 \mathrm{~mm})$ under both food-rich $(160 \mu \mathrm{g}$ $\mathrm{C} / \mathrm{L})$ and food-deprived $(7 \mu \mathrm{g} \mathrm{C} / \mathrm{L})$ conditions, if food resources for their needs occur within a suitable range. Similar results were also observed in our study, e.g., largesize gonozooids of $D$. denticulatum were mainly found in low-salinity, nutrient-rich CCC waters northwest of Taiwan, but relatively fewer gonozooids, sometimes of large body sizes, were found in the highly saline and oligotrophic KC east of Taiwan in our study area.

Distribution patterns of the thaliacean assemblage are also associated with their own physiological and ecological traits, such as swimming ability, growth rate, reproductive behavior (Gibson and Paffenhöfer 2002), and feeding behavior (Huskin et al. 2003; Kawaguchi et al. 2004). In addition to their own biological characteristics, some environmental factors, such as food sources, predators, and hydrological conditions, may directly or indirectly affect distribution patterns of thaliaceans (Deibel 1982; Kawaguchi et al. 1998; Paffenhöfer and Gibson 1999). The influences of the abovementioned factors were also evident on other gelatinous zooplankton in waters around or adjacent to Taiwan. For instance, on the northwestern continental shelf of the SCS, Li et al. (2012) suggested that local coastal upwelling and surface ocean currents driven by the SWM enhanced species numbers and abundances of siphonophores in summer; in contrast, the NEM forced the cold coastal current into the study area, resulting in low species richness and abundances in winter. López-López et al. (2013) reported recurrent higher abundances of gelatinous carnivore zooplankton in the month following a strong typhoon in northern Taiwan. In this study, D. denticulatum prevailed in shelf waters of western Taiwan in both monsoon seasons and can be used as the indicator species of the CCC. On the contrary, most salp species tended to occur in warmer oceanic waters (e.g., the $\mathrm{KC}$, $\mathrm{KBC}$, and SCSSC) east and southwest of Taiwan. There were insufficient data to illustrate distribution patterns of pyrosomids and their relationship with hydrographical variables because they were only found at a few stations in our study.

\section{Conclusions}

In conclusion, our results provide evidence that the spatio-seasonal pattern of thaliaceans is closely associated with mesoscale oceanic features in waters around Taiwan. Monsoon-driven water masses may determine 
seasonal variations in thaliacean assemblages. Distributions of abundances and size fractions of thaliaceans are influenced by hydrographic conditions due to seasonal succession of the CCC, KBC, and SCSSC, the availability of food, and their own ecological preferences. The close relationship between hydrographical factors and distributions of thaliaceans offers the possibility of using certain species as indicators of water masses that would provide a better understanding of ecosystems in the study area. This present study has expanded our knowledge of thaliacean distributions in waters surrounding Taiwan and also provides good examples of biotic responses to hydrological conditions and interactions among monsoon-driven water masses.

\section{Competing interests}

The authors declare that they have no competing interests.

\section{Authors' contributions}

WTL designed the study and coordination. ZHL and HYH carried out the studies and performed the data analysis. ZHL performed the morphological studies and drafted the manuscript. WTL wrote and edited the manuscript. All authors read and approved the final manuscript.

\section{Acknowledgements}

This research was supported by grants from the National Science Council and the Ministry of Education of the ROC to W.T. Lo (NSC98-2611-M-110-002, $00 C 030203$ of the Kuroshio Project). We thank the crew of the Fishery Researcher / for their assistance in collecting zooplankton samples and other environmental data. We are also grateful to Prof. C.-t. Shih for providing constructive comments and suggestions on the manuscript.

\section{Author details \\ ${ }^{1}$ Institute of Marine Biotechnology and Resources, National Sun Yat-sen University, Kaohsiung 80424, Taiwan. ${ }^{2}$ Institute of Marine Biodiversity and Evolutionary Biology, National Dong Hwa University, Hualien 97401, Taiwan. \\ ${ }^{3}$ National Museum of Marine Biology and Aquarium, Pingtung 944, Taiwan.}

Received: 17 January 2013 Accepted: 12 September 2013

Published: 27 November 2013

\section{References}

Alldredge AL, Madin LP (1982) Pelagic tunicates: unique herbivores in the marine plankton. Bioscience 32:655-663

Bone Q, Braconnot JC, Carre C, Ryan KP (1997) On the filter-feeding of Doliolum (Tunicata, Thaliacea). J Exp Mar Biol Ecol 214:179-193

Brandon MA, Naganobu M, Demer DA, Chernyshkov P, Trathan PN, Thorpe SE, Kameda T, Berezhinskiy OA, Hawker EJ, Grant S (2004) Physical oceanography in the Scotia Sea during the CCAMLR 2000 Survey, austral summer 2000. Deep-Sea Res II 51:1301-1321

Chen CTA, Huang MH (1996) A mid-depth front separating the South China Sea water and the Philippine Sea water. J Oceanogr 22:17-25

Chern CS, Wang J, Wang DP (1990) The exchange of Kuroshio and East China Sea Shelf waters. J Geophys Res 95:16017-16023

Chou C, Tseng LC, Ou CH, Chen QC, Hwang JS (2012) Seasonal succession of planktonic copepods in bight environments of northeastern Taiwan. Zool Stud 51(8):1380-1396

Chung SW, Jan S, Liu KK (2001) Nutrient fluxes through the Taiwan Strait in spring and summer 1999. J Oceanogr 57:47-53

Crocker KM, Alldredge AL, Steinberg DK (1991) Feeding rates of the doliolid, Dolioletta gegenbauri, on diatoms and bacteria. J Plankt Res 13:77-82

Daponte MC, Capitanio FL, Esnal GB (2001) A mechanism for swarming in the tunicate Salpa thompsoni (Foxton, 1961). Antarctic Sci 13:240-245

Deibel D (1982) Laboratory determined mortality, fecundity and growth rate of Thalia democratica Forskal and Dolioletta gegenbauri Uljanin (Tunicata, Thaliacea). J Plankt Res 4:143-153
Deibel D (1998) The abundance, distribution and ecological impact of doliolids. In: Bone Q (ed) The biology of pelagic tunicates. Oxford University Press, Oxford, pp 171-186

Deibel D, Paffenhöfer GA (2009) Predictability of patches of neritic salps and doliolids (Tunicata, Thaliacea). J Plankt Res 31:1571-1579

Dufrene M, Legendre P (1997) Species assemblages and indicator species: the need for a flexible asymmetrical approach. Ecol Monogr 67(3):345-366

Fortier L, Fevre JL, Legendre L (1994) Export of biogenic carbon to fish and to the deep ocean: the role of large planktonic microphages. J Plankt Res 16:809-839

Gibson DM, Paffenhöfer GA (2002) Asexual reproduction of the doliolid, Dolioletta gegenbauri Uljanin (Tunicata, Thaliacea). J Plankt Res 24:703-712

Godeaux J (1998) The relationships and systematics of the Thaliacea, with keys for identification. In: Bone Q (ed) The biology of pelagic tunicates. Oxford University Press, Oxford, pp 274-294

Godeaux J, Bone Q, Braconnot JC (1998) Anatomy of Thaliacea. In: Bone Q (ed) The biology of pelagic tunicates. Oxford University Press, Oxford, pp 2-24

Hsieh HY, Lo WT, Wu L, Liu DC, Su WC (2011) Comparison of distribution patterns of larval fish assemblages in the Taiwan Strait between the northeasterly and southwesterly monsoons. Zool Stud 50(4):491-505

Hsieh HY, Lo WT, Wu $\sqcup$ (2012) Community structure of larval fish from the southeastern Taiwan Strait: linked with the seasonal monsoon-driven currents. Zool Stud 51(5):679-691

Hsieh HY, Yu SF, Lo WT (2013) Influence of monsoon-driven hydrographic features on siphonophore assemblages in the Taiwan Strait, western North Pacific Ocean. Mar Freshw Res 64:348-358

Huskin I, Elices MJ, Anadón R (2003) Salp distribution and grazing in a saline intrusion off NW Spain. J Mar Syst 42:1-11

Hwang JS, Wong CK (2005) The China Coastal Current as a driving force for transporting Calanus sinicus (Copepoda: Calanoida) from its population centers to waters of Taiwan and Hong Kong during the winter northeast monsoon period. J Plankt Res 27:205-210

Hwang JS, Souissi S, Tseng LC, Seuront L, Schmitt FG, Fang LS, Peng SH, Wu CH, Hsiao SH, Twan WH, Wei TP, Kumar R, Fang TH, Chen QC, Wong CK (2006) A 5-year study of the influence of the northeast and southwest monsoons on copepod assemblages in the boundary coastal waters between the East China Sea and the Taiwan Strait. J Plankt Res 28:943-958

Jan S, Chern CS, Wang J (1994) Influence of sea surface wind stress on summertime flow pattern in the Taiwan Strait. Acta Oceanogr Taiwan 33:63-80

Jan S, Chern CS, Wang J (1998) A numerical study of currents in the Taiwan Strait during winter. Terr Atmos Ocean Sci 9(4):615-632

Jan S, Wang J, Chern CS, Chao SY (2002) Seasonal variation of the circulation in the Taiwan Strait. J Mar Syst 35:249-268

Jan S, Sheu DD, Kuo HM (2006) Water mass and throughflow transport variability in the Taiwan Strait. J Geophys Res 111, C12012

Kawaguchi S, de la Mare WK, Ichii T, Naganobu M (1998) Do krill and salps compete? Contrary evidence from the krill fisheries. Commi Cconser Antar Mar Livi Resou Sci 5:205-216

Kawaguchi S, Siegel V, Litvinov F, Loeb V, Watkins J (2004) Salp distribution and size composition in the Atlantic sector of the Southern Ocean. Deep-Sea Res || 51:1369-1381

Kremer P, Madin LP (1992) Particle retention efficiency of salps. J Plankt Res 14:1009-1015

Larson RJ, Mills CE, Harbison GR (1989) In situ foraging and feeding behaviour of Narcomedusae (Cnidaria, Hydrozoa). J Mar Biol Assoc UK 69:785-794

Li KZ, Yin JQ, Huang LM, Song XY (2012) Comparison of siphonophore distributions during the southwest and northeast monsoons on the northwest continental shelf of the South China Sea. J Plankt Res 34:636-641

Liu KK, Gong GC, Shyu CZ, Pai SC, Wei CL, Chao SY (1992) Response of Kuroshio upwelling to the onset of northeast monsoon in the sea north of Taiwan: observations and a numerical simulation. J Geophys Res 97:12511-12526

Liu KK, Tang TY, Cong GC, Chen LY, Shiah FK (2000) Cross-shelf and along-shelf nutrient fluxes derived from flow fields and chemical hydrography observed in the southern East China Sea off northern Taiwan. Continent Shelf Res 20:493-523

Lo WT, Shih CT, Hwang JS (2004) Spatial distribution of copepods in surface waters of the southeastern Taiwan Strait. Zool Stud 43:218-228

Lo WT, Kang PR, Hsieh HY (2012) Siphonophores from a transect off southern Taiwan between Kuroshio Current and South China Sea. Zool Stud 51(8):1354-1366 

variability of the gelatinous carnivore zooplankton community in northern Taiwan. J Plankt Res 35:677-683

Madin LP, Deibel D (1998) Feeding and energetics of Thaliacea. In: Bone Q (ed) The biology of pelagic tunicates. Oxford University Press, Oxford, pp 81-103 Nishikawa J, Naganobu M, Ichii T, Ishii H, Terazaki M, Kawaguchi K (1995) Distribution of salps near the South Shetland Island during austral summer, 1990-1991 with special reference to krill distribution. Polar Biol 15:31-39

Paffenhöfer GA, Gibson DM (1999) Determination of generation time and asexual fecundity of doliolids (Tunicata, Thaliacea). J Plankt Res 21:1183-1189

Paffenhöfer GA, Sherman BK, Lee TN (1987) Abundance, distribution and patch formation of zooplankton. Progr Oceanogr 19:403-409

Seapy RR (1980) Predation by the epipelagic heteropod mollusk Carinaria cristata forma japonica. Mar Biol 60:137-146

Shannon CE, Weaver W (1963) The mathematical theory of communication. University of Illinois Press, Urbana, p 125

Strickland JDH, Parsons TR (1972) A practical handbook of seawater analysis. Bull Fish Res Board Can 167:1-310

Tew KS, Lo WT (2005) Distribution of Thaliacea in SW Taiwan coastal water in 1997, with special reference to Doliolum denticulatum. Thalia democratica and T orientalis Mar Ecol Progr Ser 292:181-193

Wang J, Chern CS (1988) On the Kuroshio branch in the Taiwan Strait during wintertime. Progr Oceanogr 21:469-491

Yang Y, Liu CT, Hu JH, Koga M (1999) Taiwan current (Kuroshio) and impinging eddies. J Oceanogr 55:609-617

Zhang JB, Huang JX, Lian GS (2003a) Species composition and abundance distribution of Thaliacea in late autumn and early winter in the Nanwan Bay of Taiwan. China Mar Sci Bull 22(6):9-16

Zhang JB, Lian GS, Wang YL, Xu ZL, Chen YQ (2003b) Distribution of Thaliacea (Tunicate) in eastern Taiwan Strait. J Oceanogr Taiwan Strait 22(3):279-285

doi:10.1186/1810-522X-52-49

Cite this article as: Liao et al:: Influence of monsoon-driven

hydrographic features on thaliacean distribution in waters around

Taiwan, western North Pacific Ocean. Zoological Studies 2013 52:49.

\section{Submit your manuscript to a SpringerOpen ${ }^{\circ}$ journal and benefit from:}

- Convenient online submission

- Rigorous peer review

- Immediate publication on acceptance

- Open access: articles freely available online

- High visibility within the field

- Retaining the copyright to your article

Submit your next manuscript at $>$ springeropen.com 